\title{
CPTを用いた超小型周波数標準
}

\author{
福田京也 \\ (独) 情報通信研究機構（テ184-8795 東京都小金井市貫井北町4-2-1）
}

\section{Ultra-Compact Frequency Standards Using CPT Phenomenon}

\author{
Kyoya FUKUDA \\ NICT, 4-2-1 Nukuikita-machi, Koganei, Tokyo 184-8795
}

(Received October 10, 2006)

\begin{abstract}
In recent years, the coherent population trapping (CPT) phenomenon using a very small cell has attracted considerable attention for its potential application to ultra-compact atomic clock. For the miniaturization of CPT clock, it is important to clarify influence by the collision with atoms and cell walls. We study the effect of cell geometry on the CPT spectrum using a thin Cs vapor cell without buffer gas. When the cell length is below $1 \mathrm{~mm}$ and the laser intensity is sufficiently weak, the transit-time broadening is largely suppressed because only slow atoms have enough time to settle down on the dark state and contribute to the CPT signals. Furthermore, we show that introduction of buffer gas may broaden the CPT resonance in extremely thin cells. We also show that sub-Doppler signal which can be used for stabilization of laser frequency is obtained by using the CPT signal.
\end{abstract}

Key Words: Frequency standards, Coherent population trapping, Chip-scale atomic clock, MEMS

\section{1.はじめに}

現在，時間の単位である秒とその逆数となる周波数の 単位は，セシウム $(\mathrm{Cs})$ 原子の基底状態のマイクロ波遷移 周波数によって定義されている1)。情報通信研究機構 (NICT) は周波数の国家標準を担当する研究機関として, これまでCs原子一次周波数標準器の開発運用を行い2,3), また日本標準時を維持・管理している4). 近年の一次周波 数標準器の精度は非常に高く, 定義值に対する誤差は $10^{-15}$ (Cs原子のマイクロ波遷移周波数で規格化した值)の オーダーになる。日本標準時は商用原子時計20台の加重 平均によって運用されており, 精度は悪いが非常に安定 な時系である。したがって一次周波数標準器と商用原子 時計群は相補的な関係にあり, NICTは両者の優位点をう まく組み合わせて高精度・高安定な時系を構築, JJY (標 準電波)や電波時計, ネットワークなどを利用し社会に供 給している.

これまで高安定な発振器として水晶が広く用いられて いたが, 近年, より高安定で超小型の原子周波数基準の 開発が進み，注目を集めている ${ }^{5-9)}$. 水晶を使用せずに直 接原子のマイクロ波遷移周波数を発振する超小型発振器 の研究も進んでいる ${ }^{10,11)}$. この超小型な原子周波数基準と マイクロ波発振器を組み合わせ, 現在の水晶発振器の安 定度, 小型, 低消費電力といった性能を超える超小型デ バイスを開発することが一つの研究テーマとなってい
る。原子基準による長期周波数安定度や電磁環境に対す る高耐性などの優れた特性を利用することで，ネット ワーク同期のローカル基準源やGPS電波の届かない空間で の基準信号源などの性能向上が期待されている.そのよ うなデバイスを超小型・高安定かつ安価に市場に供給す ることができれば，社会に大きな変化をもたらすと考え られる。

本論文では，まず非常に小型の原子周波数標準器に使 われるCPT (coherent population trapping) 現象の簡単な説明 を行い，実際にCPT共鳴をマイクロ波周波数標準に応用す る際に考慮すべき事柄について, 筆者および他の研究グ ループの研究成果について述べ, 最後にこの研究テーマ の将来動向について解説する.

\section{CPT現象について}

Fig. 1 (a)に示すような状態1，2，3からなる三準位原子 を考え，それぞれの状態の波動関数を $\psi_{1}(r, t), \psi_{2}(r$, $t), \psi_{3}(r, t)$ とし，エネルギー固有值をそれぞれ $W_{1}, W_{2}$, $W_{3}$ とする.

この三準位原子の任意の状態 $\psi(r, t)$ は, 固有状態の波動 関数を用いて,

$$
\psi(r, t)=a_{1}(t) \psi_{1}+a_{2}(t) \psi_{2}+a_{3}(t) \psi_{3}
$$




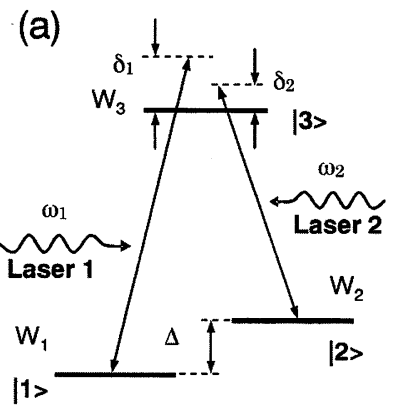

(b)

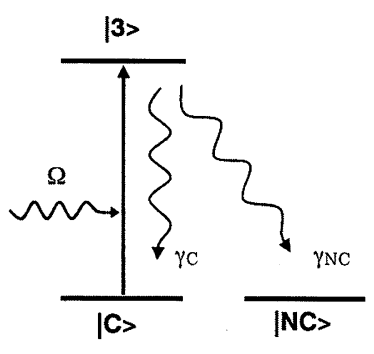

Fig. 1 Energy diagram. (a) Three atomic levels with two laser radiations. (b) Energy model with CPT phenomenon.

有状態の確率振幅である，二つのレーザー成分による摂 動ハミルトニアンを考慮したSchrödinger方程式に対し，回 転波近似を用いると, $a_{n}(t)$ は次式となる。

$$
\begin{aligned}
& \dot{a}_{1}(t)=\frac{i}{2} \Omega_{1} e^{i \delta_{1} t} a_{3}(t) \\
& \dot{a}_{2}(t)=\frac{i}{2} \Omega_{2} e^{i \delta_{2} a_{3}} a_{3}(t) \\
& \dot{a}_{3}(t)=\frac{i}{2} \Omega_{1}^{*} e^{-i \delta_{1} t} a_{1}(t)+\frac{i}{2} \Omega_{2}^{*} e^{-\delta_{2} t} a_{2}(t)
\end{aligned}
$$

ここで， $\Omega_{1}, \Omega_{2}$ は状態1と3および状態2 と3の間の遷移の ラビ周波数である。また $\delta_{1}, \delta_{2}$ はレーザー 1 抢よびレー ザー2の離調周波数である. 今, 状態 1 抢よび 2 の代わり に, 次式で定義される波動関数を持つ状態C扔よびNCを 導入する。

$$
\begin{aligned}
& \psi_{\mathrm{C}}=\frac{\Omega_{1} \psi_{1}+\Omega_{2} \psi_{2}}{\Omega} \\
& \psi_{\mathrm{NC}}=\frac{\Omega_{2}^{*} \psi_{1}+\Omega_{1}^{*} \psi_{2}}{\Omega}
\end{aligned}
$$

ここで, $\Omega=\sqrt{\left|\Omega_{1}\right|^{2}+\left|\Omega_{2}\right|^{2}}$ である. 式(1)に示した $\psi(r, t)$ は，新たに $\psi_{\mathrm{C}}$ と $\psi_{\mathrm{NC}}$ 㧍よびそれらの状態の確率振幅 $a_{\mathrm{C}}(t)$ と $a_{\mathrm{NC}}(t)$ を用いると,

$$
\psi(r, t)=a_{\mathrm{C}}(t) \psi_{\mathrm{C}}+a_{\mathrm{NC}}(t) \psi_{\mathrm{NC}}+a_{3}(t) \psi_{3}
$$

となり，

$$
\begin{aligned}
& a_{1}=\frac{\Omega_{1} a_{\mathrm{C}}+\Omega_{2}^{*} a_{\mathrm{NC}}}{\Omega} \\
& a_{2}=\frac{\Omega_{2} a_{\mathrm{C}}+\Omega_{1}^{*} a_{\mathrm{NC}}}{\Omega}
\end{aligned}
$$

となる、二つのレーザー離調周波数が等しいとき $\left(\delta_{1}=\delta_{2}\right.$ $=\delta)$, 状態3から状態C拉よびNCへの自然放出緩和レート を $\gamma_{\mathrm{C}}, \gamma_{\mathrm{NC}}$ として，式(2)を書き直すと，

$$
\begin{aligned}
& \dot{a}_{\mathrm{C}}(t)=\frac{i}{2} \Omega e^{i \delta t} a_{3}(t)+\gamma_{\mathrm{C}} a_{3}(t) \\
& \dot{a}_{\mathrm{NC}}(t)=\gamma_{\mathrm{NC}} a_{3}(t) \\
& \dot{a}_{3}(t)=\frac{i}{2} \Omega e^{-i \delta t} a_{\mathrm{C}}(t)-\gamma_{\mathrm{C}} a_{3}(t)-\gamma_{\mathrm{NC}} a_{3}(t)
\end{aligned}
$$

となる。これはFig. 1 (b)に示すように, 状態Cと状態3は
ラビ周波数 作用しないことを表している。このことから，状態Cは Coupled state, 状態NCはNon-Coupled stateと呼ばれる。原 子は状態Cから状態 $\mathrm{NC}$ 光励起され，すべての原子は状 態NCへ遷移することになる。状態NCは暗状態 (dark state) とも呼ばれる，二つのレーザー光によるコヒーレント相 互作用により，原子分布が暗状態にトラップされる。こ れがCPT現象である。

二つのレーザー周波数差に対するレーザー光の光強度 変化を観測することでCPT共鳴スペクトルが得られる， ス ペクトルピークは，二つのレーザー周波数差が原子の基 底状態間に一致したときに現れる。CsやRbなどのアルカ リ金属を用いるとマイクロ波周波数基準信号が得られ る.

CPT現象を原子時計に用いる一番大きなメリットは，マ イクロ波共振器が不要になるということである。 マイク 口波共振器を用いる従来の原子周波数標準器では, 原子 の二つの基底状態間のマイクロ波遷移によるラビ共鳴, ラムゼ一共鳴を観測し，それを周波数基準信号として用 いる，基底状態間のコヒーレンス時間が長いほど鋭い共 鳴スペクトルが得られる、コヒーレンスを長くするため に, 大きな真空装置, 長いマイクロ波共振器が必要で あった。マイクロ波共振器でコヒーレンスを作る代わり に，二つのレーザー光成分を原子に照射，この二つの レーザー成分の周波数差を原子の超微細構造間隔に一致 させることで，コヒーレンスを作ることができる.

CPT共鳴スペクトルを周波数標準に応用する場合, 重要 なパラメータは信号強度と線幅である。CPT共鳴を用いた 超小型原子標準では，得られる基準信号の周波数の絶対 值ではなく, 安定度を重視する. 周波数標準器の周波数 安定度 $\sigma_{y}(\tau)$ は, 次式で表される。

$$
\sigma_{y}(\tau) \propto \frac{1}{Q(S / N) \sqrt{\tau}}
$$

ここで， $\tau$ は平均時間， $Q$ はスペクトル信号のquality factor，S/Nは信号対雑音比である，Q值はスペクトル線幅 に反比例するため, この式から, 超小型CPT原子時計の周 波数安定度を良くするためには，スペクトル線幅を狭く し，信号強度を大きくすればよいことがわかる，信号強 度は原子数とレーザー光による光励起レートに依存し， スペクトル線幅は二つのレーザー成分で作られる基底状 態間のコヒーレンスに依存する。

\section{CPT共鳰の観測}

周波数標準器を小型化する場合，原子を小さな容器に 閉じ达めて，レーザーとのコヒーレント相互作用を起こ させる必要がある。一般には光学的に透明なガラスセル に原子を封入し，レーザーを照射，その透過光強度を観 測する．ガラスセルが小さいほど，原子はガラス壁面に 衝突しやすくなり，コヒーレンスが失われることが予想 される. 小さなガラスセルに閉じ込められた原子の位相 緩和時間とセル形状寸法との相関を調べることは, 超小 
型CPT原子時計の性能を評価する上で重要である.

CPT共鳴線に対するセル寸法の影響について，筆者らの 実験結果を紹介する12)。実験ではセルの長さの異なるCs 原子封入ガラスセルを用意し，CPT線幅を測定した $(F i g$. 2). 円筒状のガラスセルの二つの平らなガラス壁面間距 離を変え，セル内の原子とこの壁面との衝突緩和効果を CPT共鳴によって調べる．Fig. 3 (a)に長さ1 mmのガラス セルを用いて観測した典型的なCPTスペクトルを示す. レーザー光は平らなガラス壁面に垂直方向から入射し, $9.192 \mathrm{GHz}$ の位相変調器により $\Lambda$ 型共鳴を生じる二つの レーザー成分を持つ。セルを透過したレーザー光強度を 高感度光検出器で測定し, CPTスペクトルを観測する.

セルは一重の磁気シールド内に置き, ソレノイドコイル

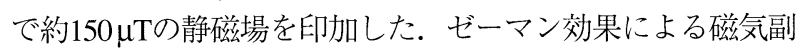
準位の分裂から生じた7つのCPTスペクトルが観測されてい る. 基底状態間遷移 $\left(F=3, \quad m_{F}=0\right) \leftrightarrow\left(F=4, m_{F}=0\right)$ の コヒーレンスに相当するCPTスペクトル (Fig. 3 (a)では $(0$, 0)と表記)に注目し，そのスペクトル線幅のレーザー光強度 依存性を調べた。この $(0,0)$ 成分は外部磁場に対し一次の周 波数シフトを持たないため，周波数基準信号に用いられ る. Fig. 3 (b) に，三つの異なるセル長さ $(40 \mathrm{~mm}, 1 \mathrm{~mm}, 0.3$ $\mathrm{mm})$ のセルを用いた時の信号線幅のレーザー光強度依存性 を示す. $40 \mathrm{~mm}$ セルの場合，強度広がりによる線形な傾向が 観測されている，七ル長さが短い場合 $(<1 \mathrm{~mm})$, 光強度が 弱くなるに従って，異なる依存性が現れる。この特性を壁 面との衝突効果を考慮したレート方程式モデルを用い解析 した結果，短いセル中では速度の遅い原子だけが光と十分

(a)

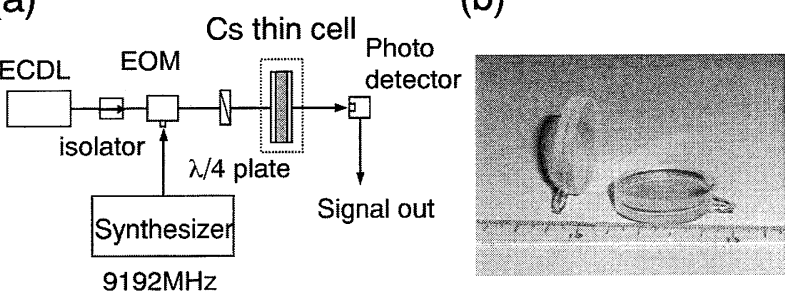

Fig. 2 (a) Schematic diagram of experimental setup. (b) Cesium thin cell. This figure shows cells with 0.2mm wall-to-wall gap. (a)

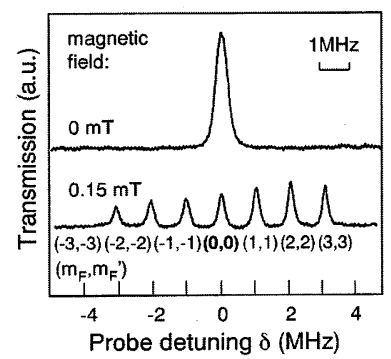

(b)

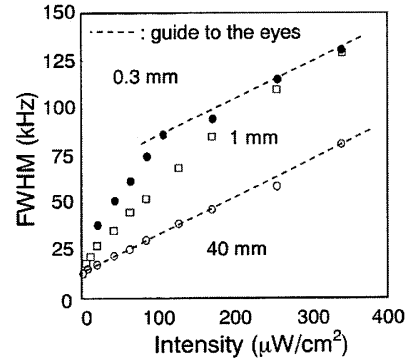

Fig. 3 (a) Typical CPT spectra observed with $1 \mathrm{~mm}$ cell. Laser transmitted power is measured as function of frequency of synthesizer. (b) Dependence of linewidth of observed CPT spectrum on laser intensity.
な相互作用時間を持ち，暗状態に遷移し，CPT信号に寄与す ることがわかった．同様の結果が文献13で報告されている.

この実験結果から，原子と壁面との衝突による緩和効 果はCPT共鳴線幅に大きな影響を与えることがわかった. より積極的に壁面との衝突による緩和効果を小さくする 手法として，ガラス壁面にテフロンやパラフィンなどの 緩衝物質を被覆したセルを用いる方法や，ガス状の緩衝 物質(バッファガス)をセル内に封入する方法がある。ここ では一般によく使われているバッファガスを用いる方法 を紹介する。

CPT信号線幅は，原子とレーザーとの相互作用時間に よって決まる，通常の蒸気セルにおける熱平衡状態の原 子は，数百 $\mathrm{m} / \mathrm{s}$ の速度を持って運動している. $\mathrm{mm}$ サイズ のセルの場合, マイクロ秒程度でコヒーレンスが消失し てしまう。バッファガスを封入すると，原子とガスとの 弾性衝突により，原子の飛行時間が長くなり，相互作用 時間を数ミリ秒以上にすることも可能である.

原子の共鳴周波数は，バッファガスと原子との衝突に よってシフトする. 周波数シフトの圧力係数はバッファ ガスの種類に依存する. 超微細構造遷移周波数に対する バッファガス圧力依存性 ${ }^{14)}$ や高バッファガス圧力による スピン交換相互作用の影響が調べられている15). 圧力係 数が同程度で, 逆符号のガスを混合して用いると, 衝突 シフトを小さくすることも可能である $\left(\mathrm{Ne}+\mathrm{Ar}, \mathrm{N}_{2}+\mathrm{Ar}\right.$ 等). CPT共鳴線幅のバッファガスセルの長さに対する依 存性がKnappeらによって報告された16). Fig.4に文献13お よび文献16のデー夕と著者らの結果を重ねて示す。縦軸 はレーザー光強度が 0 に相当する線幅を，横軸はセルの長 さを表している。図の文献16のデータは，バッファガス が $\mathrm{Ne}$ ，圧力が $4 \mathrm{kPa}$ の場合である。実験ではガス圧力や壁 面間距離を変化させるための真空装置を用いている。十 分高いバッファガス圧力の場合，信号線幅 $v_{\mathrm{CPT}}$ は次の関係 式に従う17).

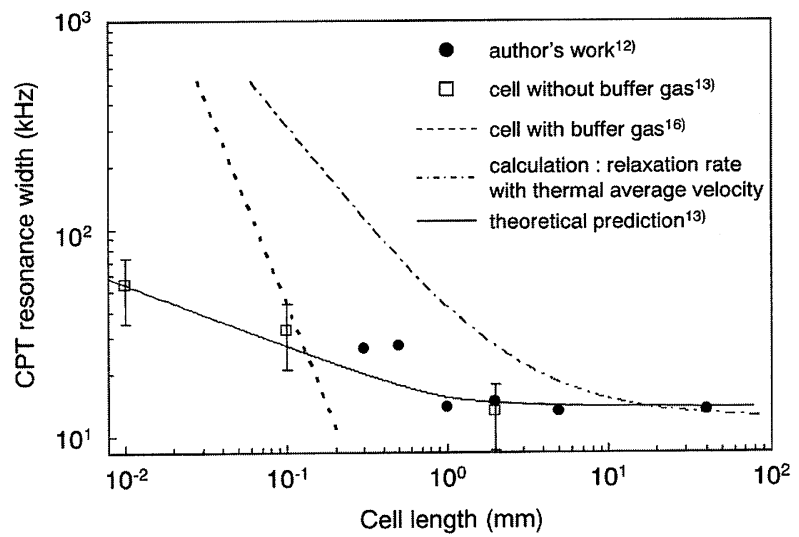

Fig. 4 Dependence of CPT linewidth on cell length. Results of theoretical calculation from ref13) is shown in this figure (solid line). Relaxation rate was calculated using the thermal average velocity for atoms at room temperature (alternating long and short dashed line). 


$$
v_{\mathrm{CPT}} \propto A p+\frac{B}{p L^{2}}
$$

ここで $p$ はバッファガス圧力，Lはセル長さ，A，Bは定数 である、第一項はバッファガスと原子との衝突による広 がり効果を表し，第二項はバッファガス中を拡散運動す る原子とセル壁面との衝突による広がり効果を表す。文 献16で報告された実験では0 $0.8 \sim 8 \mathrm{kPa} 9 \mathrm{Ne}$ ガスを用いてい るが，この関倸式をほほ满足する結果が得られている。

実験手法が異なることやバッファガスの種類や圧力に よって信号線幅は大きく変化することなどから単純な比 較はできないが，バッファガスを入れないセルでも十分

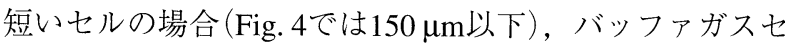
ルの線幅よりも狭くなっている。バッファガスがない場 合，自由飛行する原子と壁面との衝突による広がり効果 が主である，その場合，原子の速度分布が線幅に大きな 影響を与えるであろうことは容易に想像できる．Fig. 4の 一点鎖線は熱的平均速度を用いて計算した依存性である が，実際に観測された線幅は熱的平均速度から求めた線 幅よりも狭くなっている。これは短いセルでは速度の遅 い原子のみが信号に寄与するためである。バッファガス ありとなしのセル長さ依存性の違いは信号に寄与する原 子の速度に起因すると考えられる。

文献18に扔いて，信号強度の七ル温度に対する依存性 も報告されている，温度を上げると原子密度が上昇し， 信号強度が増大寸る。しかし原子密度が大きくなると， optical thickness効果により信号コントラストが減少する. 高温になるにつれて原子同士のスピン交換相互作用によ り信号線幅が広がる効果も現れてくる，原子密度が小さ い場合には，得られる信号形状はローレンッ型で仮定で き，簡単な三準位系で解析できるが，原子密度が大きい 場合には，三準位モデルは成り立たず，解析が複雑にな る。またバッファガスによって光ポンピング効率が低下 し信号強度も減少するが，信号強度を上げようと光強度 を強くすると強度広がり効果により信号線幅が広がる。 またCPT共鳴に寄与しない準位へ光励起される原子が増え るため，信号強度が低下するという問題も生じる。バッ ファガスの種類によっても特性は異なり，簡単に最適な 条件を見つけることは難しいが，これらの影響を考慮 し, MEMS (Micro Electro Mechanical Systems, 微小電気機 械システム)技術を用いた最初の超小型原子時計 (chipscale atomic clock: CSAC) がNISTグループにより報告され た6). Cs 原子の $\mathrm{D}_{2}$ 線を用い，レーザー光源とガラスセル， 光検出器が一体になったphysics packageは, 体積 $9.5 \mathrm{~mm}^{3}$, 温度 $85^{\circ} \mathrm{C}$, 得られた周波数安定度は 1 秒平均で $2.5 \times 10^{-10}$, 消費電力 $75 \mathrm{~mW}$ であった，微小セル生成過程で生じる不純 物の影響により, $-2 \times 10^{-8} / \mathrm{day}$ の線形な周波数ドリフトが 観測されている.

\section{4. 周波数安定度を向上させる方法}

これまでに，CPT信号の線幅およびSN比を改善する手 法が数多く提案されている. 研究の初期において, 光源
の入手しやすさから，CsやRb原子の $\mathrm{D}_{2}$ 線が用いられてい た。最も有効な手法は， $\mathrm{D}_{2}$ 線の代わりに $\mathrm{D}_{1}$ 線を用いる力 法である ${ }^{19)}$. $\mathrm{D}_{2}$ 遷移は励起状態に多くの超微細構造を持 ち，その周波数間隔は数百 $\mathrm{MHz}$ と近接している。バッ ファガスと原子との衝突により励起準位の寿命は短くな り, 数百MHz程度の衝突広がりを持つ。この広がりは隣 接する超微細構造の広がりと重なるため, 光ポンピング 効率を低下させる。すすおわちCPT共鳴に寄与しない原子が 増え，信号コントラストが小さくなる。 $\mathrm{D}_{1}$ 遷移の場合, 超微細構造間隔は数 $\mathrm{GHz}$ 程度と周波数間隔は広いため, 光 ポンピング効率の低下を防ぐことができる． $\mathrm{D}_{2}$ 線と比較 し, 約10倍の信号強度が得られた19).

その他の方法として，スピン交換相互作用の弱いend transition (Cs 原子の場合, $m_{F}=3$ や- 3準位)を使う方法20) 磁気量子数 $m_{F}=0$ 間の $\Lambda$ 型遷移共鳴信号を強める push-pull 光ポンピング方法が提案された ${ }^{21)}$.またレーザー光をパ ルス状に照射，干渉効果によりCPT線幅を狭窄化する pulsed CPT法 ${ }^{22)}$ ，N-resonance excitation 法 ${ }^{23)}$ ，二つの面発 光レーザーを用いるdifferential CPT法 ${ }^{24)}$ が，これまでに提 案されている。これらの手法は微小セルを使うときに有 効と思われるが，システムやその設計が複雑になるとい う一面もある。

$\mathrm{D}_{1}$ 遷移のCPTを用いる手法を実際のCSACに応用し，周 波数安定度を評価した結果がKnappeらによって報告され ている ${ }^{25)}$. 用いる原子遷移を $\mathrm{Cs}_{2}$ 線から $\mathrm{RbD}_{1}$ 線にし，微 小セル中の原子の純度を向上させ，1000秒の平均化時間 で $6 \times 10^{-12}$ の周波数安定度を実現した。またGerginovら は，CSACの周波数安定度に対する，マイクロ波変調パ ワー依存性を調べ，最適な変調指数に打汸周波数安定 度を評価している26)。

\section{CPT信号のレーザー周波数安定化への応用}

また筆者らは，速度の遅い原子によるCPT信号のレー ザー周波数安定化への応用の可能性を調べたので結果を 紹介する27)。一般にCPT共鳴を観測する場合， $\Lambda$ 型共鳴を 起こす二つのレーザーはそれぞれ原子の共鳴周波数にほ ぼ同調させる．この二つのレーザー周波数の差が基底状 態間遷移周波数に一致するときに，透過光強度がピーク となる、 $\Lambda$ 型共鳴を保ちつつ，レーザー周波数を変化させ るとどうなるであろうか，その場合ドップラー効果によ り，CPT共鳴に主に寄与する原子の速度分布を変えること ができる、レーザーの周波数が原子の共鳴周波数からず れると， CPT共鳴に寄与する原子速度が徐々に大きくな る。短いセルほど，このレーザー離調周波数の影響が顕 著である。すなわち，少しでも壁面方向の速度成分を持 つと, 原子はすぐに壁面と衝突緩和してしまう。その結 果, 信号強度は急激に小さくなり，信号線幅も広がる。 CPT 共鳴のピーク付近の共鳴の鋭さ, 曲率 (2-fロックイン 検波出力)をレーザー離調周波数の関数としてプロットす ると, サブドップラー構造が観測でき，短いセルほど構 造が顕著に現れるようになる。得られた信号形状は Liouville方程式の定常状態解によって再現することができ 
た27)、レーザー周波数の安定化には誤差信号が必要であ るが，この方法により実際に得られた誤差信号(3-f検波信 号)をFig. 5 (a)に，そのときの2-f検波出力をFig. 5 (b)に 示す. 実験はCs $\mathrm{D}_{2}$ 線を用いて行い, $F=4 \leftrightarrow F=3$ 遷移と $F=4 \leftrightarrow F=4$ 遷移に対応する二つの信号ピークが観測さ れている。 $\mathrm{D}_{2}$ 線の超微細構造間隔は狭いため, 二つの信 号成分の裾は重なっている。この重なりは $\mathrm{D}_{1}$ 線を用いる ことで解消できる。ここで紹介した方法は, マイクロ波 周波数とレーザー周波数を同時に決めることができるユ ニークな手法と言える。

\section{6. 今後の展望}

小型原子時計への応用を念頭に入れ，近年CPT共鳴の 様々なパラメータ依存性を調べた研究グループとして, これまでにNIST, Princeton大, BNM-SYRTE, HSAO, NICT等が挙げられる. CPT共鳴を用いて実際に超小型の プロトタイプ装置を開発したグループとして, NIST, Symmetrycom社, Honeywell社が挙げられる. 超小型CPT 原子発振器の現状の性能は, およそ次の通りである.

- Physics package: $10 \mathrm{~mm}^{3}$

·体積 (発振器, 制御系の電子回路を含む) : $10 \mathrm{~cm}^{3}$

·消費電力 $: 200 \mathrm{~mW}$

. 周波数安定度 $(\mathrm{Cs}$ 遷移周波数で規格化)： $1 \times 10^{-11} @$ hour, $1 \times 10^{-10} @$ day NISTおよびSymmetrycom社は, 体積 $1 \mathrm{~cm}^{3}$, 消費電力 30 $\mathrm{mW}$, 周波数安定度 $1 \times 10^{-11} @$ hourの実現を目標にしてい る. 周波数安定度に関しては目標をクリアしているが, 現状ではまだ消費電力が大きいことがわかる．消費電力 $30 \mathrm{~mW}$ 以下になれば，現状の性能のバッテリーが電源とし て使用でき，CSACの応用範囲も拡大すると考えられる。 周波数安定度をよくするために，七ル温度を上げてい る。この温度制御に約 $1 / 3$ 電力が消費されている， $\mathrm{Rb}$ 原

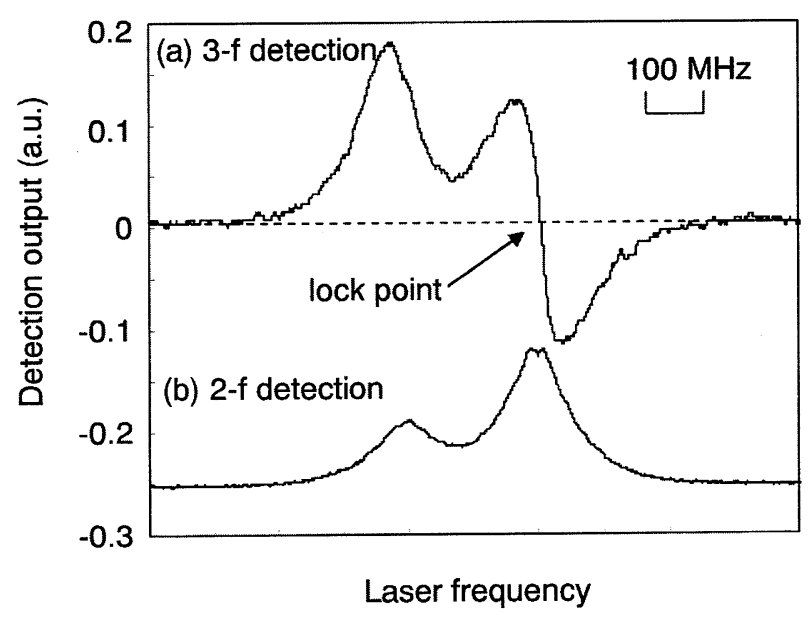

Fig. 5 (a) Third harmonic detection (3- $f$ detection) signal. (b) Second harmonic detection (2-f detection) signal. Zero point frequency of $3-f$ detection output corresponds to peak signal of $2-f$ detection output, which is equal to $F=4-F^{\prime}=4$ transition frequency of $\mathrm{Cs}$ atom.
子はCs原子よりも融点が高いため, 同じ原子密度を達成 するためにはより高温にする必要がある。また遷移強度 に関して， $\mathrm{D}_{2}$ 遷移よりも $\mathrm{D}_{1}$ 遷移の方が小さいため, $\mathrm{D}_{1}$ 線 で $\mathrm{D}_{2}$ 線と同じ信号強度を得るためにはさらに原子密度を 上げる必要がある。原子密度が上がるとスピン交換相互 作用の影響やoptical thickness効果の影響が生じることは前 述した通りであり，原子時計の性能を支配するメカニズ ムは複雑である，原子密度を上げずに信号強度を増大さ せる手法の開発が待たれる。

エレクトロニクス系の小型化も今後の課題である. 超 小型原子時計は, それ自体は発振器ではなく単なる周波 数基準にすぎない. 電圧制御発振器 (VCO)などの発振周 波数を原子の共鳴周波数に同調する必要がある. 現在, MEMS技術を用いて直接マイクロ波周波数を発振する超 小型VCOの開発が進んでいる。高性能CSAC開発において は, $\mathrm{VCO}$ の低ノイズ化, 光源との整合なども重要な研究 テーマである.

将来動向について, 現状で考えられる可能性を述べ る. 一つの方向性は, 現状のCSACの小型化が進み, 携带 電話や通信デバイス, GPS装置に組み込まれるケースであ る.NISTをはじめとする多くの機関はこの方向で研究を 進めている. 同じ方向性であるが, もう少しデバイス寄 りの側面として，Si基板上にすべてまとめてしまう方向性 も考えられる. KnappeらはMEMS技術を用いて Si基板を用 いCSACのphysics packageを製作した6). SiTime社はSOI基 板と $0.18 \mu \mathrm{m}$ ルールのCMOS技術を用いてMEMS共振器を 製作した ${ }^{28)}$ 。これらのシステムを一つの基板，一つの packageにまとめ, 一つのデバイス (System On Package: SOP) で様々な機能を持たせるような研究開発も今後進む 可能性がある29).

\section{7. まとめ}

CPT現象を用いた超小型原子時計をテーマに, CPT現象 の初歩的なメカニズムの説明, 筆者らの研究結果, 他の 研究グループの成果を紹介し, CSACの現状および将来動 向を述べた。原子時計の小型化に関して，まだ乗り越え なくてはならない障壁があるが，技術の進歩に伴いクリ アされるだろう。周波数標準という少し堅い研究分野か ら，様々な機能を一つにまとめるという日本企業の得意 とする手法を生かし，イノベーションを創造するテーマ が出てくることを期待したい.

\section{参考文献}

1) 訳・監修工業技術院計量研究所：国際単位系 (SI) -グロー バル化社会の共通ルールー日本語版 国際文書第7版 (1998).

2) K. Nakagiri, M. Shibuki, S. Urabe, M. Ishizu, T. Morikawa, and Y. Saburi: Proc. $38^{\text {th }}$ Frequency Control Symposium (1984) p. 447.

3) A. Hasegawa, K. Fukuda, M. Kajita, H. Ito, M. Kumagai, M. Hosokawa, N. Kotake, and T. Morikawa: Metrologia 41 (2004) 257.

4）中川 史丸, 花土ゆう子, 今村國康, 小竹昇, 清水義行, 高橋幸雄, 細川瑞彦, 森川容雄: 電気学会電子回路研究会 資料 ECT-06-70 (2006).

5) J. Kitching, S. Knappe, and L. Hollberg: Appl. Phys. Lett. 81 (2002) 
553.

6) S. Knappe, V. Shah, P. D. D. Schwindt, L. Hollberg, J. Kitching, L. A. Liew, and J. Moreland: Appl. Phys. Lett. 85 (2004) 1460.

7) R. Lutwak, J. Deng, W. Riley, M. Varghese, J. Leblanc, G. Tepolt, M. Mescher, D. K. Serkland, K. M. Geib, and G. M. Peake: Proc. of the $36^{\text {th }}$ Annual Precise Time and Time Interval Systems and Applications Meeting (2004) p. 339.

8) R. Lutwak, P. Vlitas, M. Varghese, M. Mescher, D. K. Serkland, and G. M. Peake: Proc. 2005 Joint IEEE International Frequency Control Symposium and Precise Time and Time Interval Systems and Applications Meeting (2005) p. 752.

9) J. Kitching, S. Knappe, L. Liew, J. Moreland, P. D. D. Schwindt, V. Shah, V. Gerginov, and L. Hollberg: Metrologia 42 (2005) S100.

10) S. Fujii, Y. Takada, and H. Harima: Proc. IEEE Frequency Control Symposium (2005) p. 499.

11) S. Gribaldo, C. Chay, E. Tournier, and O. Llopis: IEEE trans. Ultrason. Ferr. Freq. Control 53 (2006) 1982.

12) K. Fukuda, M. Kinoshita, A. Hasegawa, M. Hosokawa, and M. Tachikawa: Proc. Asia-Pacific Workshop on Time and Frequency 2002 (2002) p. 116.

13) H. Failache, A. Lezama, D. Bloch, and M. Ducloy: 8th European Conference on Atomic and Molecular Physics (2004).

14) M. Arditi and T. R. Carver: Phys. Rev. 124 (1961) 800.

15) A. Corney: Atom. and Laser Spectro. (1977) p. 604.

16) S. Knappe, L. Hollberg, and J. Kitching: Opt. Lett. 29 (2004) 388.
17) N. Beverini, P. Minguzzi, and R. Strumia: Phys. Rev. A 4 (1971) 550.

18) S. Knappe, J. Kitching, L. Hollberg, and R. Wynands: Appl. Phys. B 74 (2002) 217.

19) M. Stahler, R. Wynands, S. Knappe, J. Kitching, L. Hollberg, A. Taichenachev, and V. Yudin: Opt. Lett. 27 (2002) 1472.

20) Y. Y. Jau, A. B. Post, N. N. Kuzma, A. M. Braun, M. V. Romalis, and W. Happer: Phys. Rev. Lett. 92 (2004) 110810.

21) Y. Y. Jau, E. Miron, A. B. Post, N. N. Kuzma, and W. Happer: Phys. Rev. Lett. 93 (2004) 160802.

22) T. Zanon, S. Guerandel, E. de Clercq, D. Holleville, N. Dimarcq, and A. Clairon: Phys. Rev. Lett. 94 (2005) 193002.

23) I. Novikova, D. F. Phillips, A. S. Zibrov, R. L. Walsworth, A. V. Taichenachev, and V. I. Yudin: Opt. Lett. 31 (2006) 2353.

24) V. Shah, S. Knappe, P. D. D. Schwindt, V. Gerginov, and J. Kitching: Opt. Lett. 31 (2006) 2335.

25) S. Knappe, V. Gerginov, P. D. D. Schwindt, V. Shah, H. G. Robinson, L. Hollberg, and J. Kitching: Opt. Lett. 30 (2005) 2351.

26) V. Gerginov, S. Knappe, V. Shah, P. D. D. Schwindt, L. Hollberg, and J. Kitching: J. Opt. Soc. Am. B 23 (2006) 593.

27) K. Fukuda, A. Toriyama, A. Izmailov, and M. Tachikawa: Appl. Phys. B 80 (2005) 503.

28）江刺 正喜：日経エレクトロニクス，4/10号 (2006) p. 125.

29) R. R. Tummala: IEEE Spectrum, June (2006) p. 38.

\section{コヒーレントポピュレーショントラッピング}

\section{(coherent population trapping; CPT)}

コヒーレント光による原子の励起過程において，複数 個のエネルギー準位が別の共通の準位と結合している場 合，二光子共鳴条件下で量子干渉効果により，一部の原 子は複数個の準位のコヒーレントな重ね合わせ状態にト ラップされたままになる現象．重ね合わせの状態と共通 準位との間の光学遷移は禁制となるため, 光学的に結合 しない.この重ね合わせ状態は暗状態 (dark state) とも呼ば れる. 暗状態の原子は光を吸収しないため, 光ポンピン
グを利用し信号強度を増大させることを目的とする実験 では，その効率を低下させる現象として捉えられる。し かしながらCPT効果は非常に限られたドップラー速度成分 を持つ原子のみに起こるためレーザー冷却に応用され る。またマイクロ波周波数で変調したレーザー光を使っ て CsやRb原子に対するCPT効果を利用すると，これまで 周波数標準信号取得に必要だったマイクロ波共振器が不 要になるため, 超小型原子時計が実現できる.

(福田京也) 